\title{
Seasonal and three-year variability of meiobenthic nematode populations at two estuarine sites*
}

\author{
Richard A. Eskin**, Bruce C. Coull*** \\ Belle W. Baruch Institute for Marine Biology \& Coastal Research, Department of Biology and Marine Science Program, \\ University of South Carolina, Columbia, South Carolina 29208, USA
}

\begin{abstract}
Three yr of continuous sampling of nematode species at 2 South Carolina estuarine sites (1 sand, $1 \mathrm{mud}$ ) indicate different species assemblages, abundance and seasonal patterns. Year-to-year variability was not great and was similar at both sites. The mud species were distinctly seasonal; the sand community lacked distinct seasonality. Juvenile fish predation probably controlled the seasonal population changes at the mud site, whereas at the sand site the lack of seasonality is thought to be due to an active hydrodynamic regime which maintained the fauna at a relatively constant abundance. While 98 species were identified from the mud and 123 from the sand, only 6 in mud and 5 in sand were high enough in relative abundance to each comprise $3 \%$ or more of the total nematodes. These 11 species are discussed in detail. Correlation of nematode species abundance (and their life stages, e.g. female, male, juvenile) with physical (temperature, salinity, Redox depth) and biological factors (diatom, bacteria abundance) were uninformative. There were no more significant correlations than expected by chance. Neither a gravid female nor a juvenile maximum preceded the abundance maximum of any species suggesting that either the generations were overlapping and/or the nematodes had a continuous or protracted reproductive activity.
\end{abstract}

\section{INTRODUCTION}

Temporal studies of marine meiobenthos have traditionally been directed toward describing trends in abundance variability at the major taxon level (e.g. nematode, copepod, etc.). When species composition and population life-history stages (e.g. males, females, juveniles, etc.) are included, the studies tend to be of short duration $(<2 \mathrm{yr})$ or limited to one or a few closely clustered points in time. The seasonal pattern(s) discerned in such short-interval studies are typically inferred to be the seasonal pattern(s) of the species in question. For nematode species there are only a few studies that investigate seasonal fluctuations for periods longer than 1 yr. Boucher (1983) reported on widely spaced samples from the Bay of Morlaix, France over $10 \mathrm{yr}$, and Gourbault $(1984,1987)$ reported on nematode assemblages from unreplicated samples taken once in 1978, once in 1979 and then 3 times a

- Contribution No. 687 from the Belle W. Baruch Institute for Marine Biology and Coastal Research

- Present address: Illinois Legislative Research Unit, 222 South College, 3rd Floor, Suite A, Springfield, Mlinois 62704 , USA

-. Addressee for correspondence year in 1980 to 1983 , following an oil pollution event in early 1978. To date, no studies consider the population dynamics of marine nematode species based on replicated and continuous sampling for greater than 1 to 2 yr.

In this paper we report on 3 yr (1980-1982) of continuous sampling of the meiobenthic nematode taxocene at 2 subtidal sites ( $1 \mathrm{mud}$, and 1 sand) in a Southeastern United States salt marsh complex. Nematodes numerically comprised 69 and $52 \%$ of the total meiofauna at the mud and sand site, respectively, and were the dominant taxon at each site (Coull 1985). The present study examines the dominant nematode species-abundance patterns over time and the inherent community patterns within these nematode taxocenes.

This research was conducted at the Belle W. Baruch Institute for Marine Biology and Coastal Research's North Inlet Estuarine system, near Georgetown, South Carolina, USA, the only marine/estuarine site in the National Science Foundation's Long-Term Ecological Research network. North Inlet is a natural undisturbed ecosystem maintained for conservation and research; thus, it is an ideal setting to measure natural changes, fluctuations and trends in populations. Questions central to this research include: How do natural popula- 
tions fluctuate, i.e. is there continuity over time in abundance and/or species abundance? What factors control the changes or the continuity? Are there different seasonal or year-to-year patterns in sand and mud assemblages separated by less than $2 \mathrm{~km}$ ? Does ovigerous female abundance precede juvenile abundance, and does the latter precede total abundance?

\section{METHODS AND MATERIALS}

Field and laboratory. Details of meiofauna sampling/extraction and collection of the associated physical data are presented in Coull (1985). At the mud site (Bread \& Butter Creek) and the sand site (Debidue sand bar) 3 replicate core samples were taken monthly in $1980 ;$ in 1981 and 1982 two replicate samples were taken fortnightly. All cores were taken to the depth of the redox potential discontinuity (RPD): $2 \mathrm{~cm}$ in mud, 7 to $10 \mathrm{~cm}$ in sand. Both sites were subtidal, located $0.5 \mathrm{~m}$ below MLW. Meiofauna extraction from mud was by Ludox centrifugation (de Jonge \& Boumann 1977); sand sample extraction by shaking-decantation (Wieser 1960). All animals retained on a $63 \mu \mathrm{m}$ sieve were counted and enumerated to major taxon. Every fourth nematode (up to a total of 100 per replicate) was removed, placed in glycerine-alcohol, dehydrated (Seinhorst 1959) and mounted in glycerine for identification. Each removed nematode was identified to species, sexed, assessed as to status of eggs and defined as juvenile or adult. All nematode data are presented as number per $10 \mathrm{~cm}^{2}$ following the recommendation of Hicks \& Coull $(1983$, p. 83) to avoid percentage data.

Data analyses. All data have been stored on the University of South Carolina's IBM 3801 computer as SAS (SAS Institute 1982) data sets. Data manipulation, statistical and graphical summarization utilized SAS software (SAS 1982). Tests of significance were accepted as significant at alpha $=0.05$. Divisions of the year for tests of seasonal difference in species abundance were January to March (winter), April to June (spring), July to September (summer), October to December (autumn). ANOVAs tested for seasonal and year-to-year differences; Tukey's studentized range test (SAS 1982) was employed to find which seasons differed. This test utilized harmonic means because cell sizes were unequal.

Total abundance and abundance of each life history stage (e.g. female, juvenile, etc.) of the 11 dominant species were correlated (Pearsons correlation coefficient) with 3 physical variables (e.g. temperature, salinity, depth of the RPD) and 2 biological variables (e.g. number of diatoms, number of bacteria). The diatombacteria correlations were done for 1981 only, the only

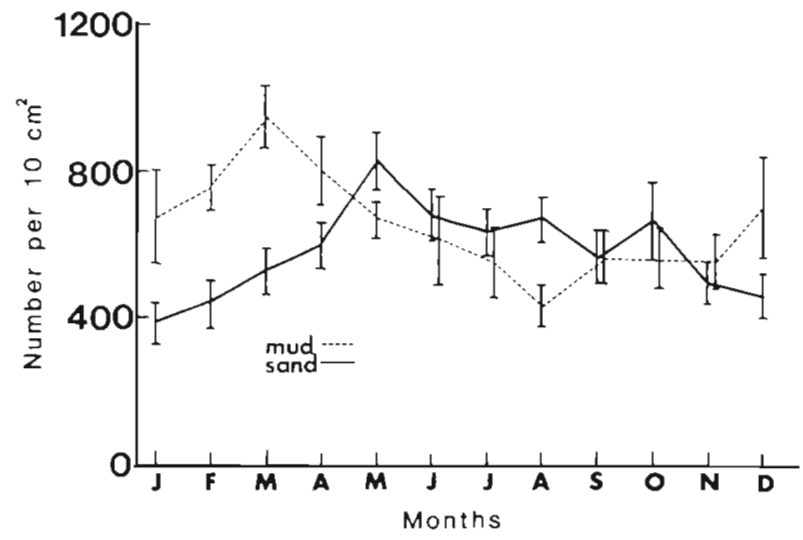

Fig. 1. Monthly mean abundance ( $\pm S E$ ) of total nematodes (i.e. all 3 January's, etc.) at the mud and sand sites

year simultaneous collections were made (Montagna et al. 1983). To maintain an experiment-wise error rate of $\mathrm{p}=0.05$ only correlations of $\mathrm{p} \leq 0.01$ were accepted as significant (Bonferroni inequality, Kirk 1982, p. 106).

\section{RESULTS}

Details of the physical factors are provided in Coull (1985). Briefly, temperature, salinity and RPD depth varied seasonally at both sites with maximum temperatures and shallowest RPD depth in August and minimum salinities in late winter/early spring (see Coull 1985, Fig. 2). Neither temperature nor salinity nor RPD depth was significantly different among the 3 yr. At the mud site, sediment median grain size (mgs) ranged between 29 and $63 \mu \mathrm{m}$, sorting coefficient (So) between 0.95 and $2.50(\overline{\mathrm{x}}=1.46)$ and percent silt-clay (\% SC) between 59 and $69 \%$. At the sand site median grain size ranged between 173 and $197 \mu \mathrm{m}$ $(\bar{x}=1.86 \mu \mathrm{m})$, sorting coefficient between 1.2 and 1.4 $(\bar{x}=1.24)$ and percent siltclay between 5.5 and $16.6 \%$ $(\overline{\mathrm{x}}=12.3)$.

A total of 8112 nematodes (98 nominal species) were identified from the mud site, and 6602 (123 nominal species) from the sand site (Eskin 1985). Fig. 1 illustrates the monthly mean abundance (i.e. mean of all 3 January's, all 3 February's etc) of the total nematodes at both sites. Mean mud site abundance was 641 per $10 \mathrm{~cm}^{2}$; mean sand site abundance 583 per $10 \mathrm{~cm}^{2}$; slightly lower than the abundances of 856 (mud) and 641 (sand) per $10 \mathrm{~cm}^{2}$ reported by Coull (1985) for $11 \mathrm{yr}$ at these sites. Since there were so many nematode species, those that did not comprise at least 3\% (by number) of the total nematode fauna overall at each site are not presented. The species not discussed were present in such low abundances that there were insufficient individuals to allow statistically reliable testing or 
Table 1. Dominant species listed by feeding types at the 2 sites. Feeding types are general descriptions of the likely food resources for that species, with Wieser's (1953) code in parentheses. Abundance is the mean abundance per $10 \mathrm{~cm}^{2}$ for collections from 1980 to 1982 . $\mathrm{n}=114$ at the mud site; $\mathrm{n}=109$ at the sand site

\begin{tabular}{|c|c|c|c|c|c|c|}
\hline \multirow[b]{2}{*}{ Feeding type } & \multicolumn{3}{|c|}{ Mud site } & \multicolumn{3}{|c|}{ Sand site } \\
\hline & Species & $\begin{array}{l}\text { Abundance } \\
\text { (ind } 10 \mathrm{~cm}^{-2} \text { ) }\end{array}$ & Rank & Species & $\begin{array}{l}\text { Abundance } \\
\text { (ind } 10 \mathrm{~cm}^{-2} \text { ) }\end{array}$ & Rank \\
\hline \multirow[t]{3}{*}{$\begin{array}{l}\text { Deposit } \\
\text { (1B) }\end{array}$} & $\begin{array}{l}\text { Sabatieria americana } \\
\text { Timm }\end{array}$ & $103 \pm 72$ & 1 & $\begin{array}{l}\text { Sabatieria armata } \\
\text { Gerlach }\end{array}$ & $19 \pm 23$ & 3 \\
\hline & $\begin{array}{r}\text { Daptonema erectum } \\
\text { (Weiser \& Hooper) }\end{array}$ & $84 \pm 59$ & 2 & Daptonema sp. & $38 \pm 39$ & 1 \\
\hline & Sabatieria kelleti Platt & $40 \pm 42$ & 3 & & & \\
\hline \multirow[t]{2}{*}{$\begin{array}{l}\text { Herbivore } \\
\text { (2A.) }\end{array}$} & $\begin{array}{l}\text { Ptycholaimellus hiber- } \\
\text { nus Eskin \& Hopper }\end{array}$ & $38 \pm 51$ & 4 & $\begin{array}{l}\text { Pomponema macro- } \\
\text { spiralis (Ott) }\end{array}$ & $18 \pm 20$ & 4 \\
\hline & $\begin{array}{l}\text { Dorylaimopsis meta- } \\
\text { typica Chitwood }\end{array}$ & $24 \pm 26$ & 5 & $\begin{array}{l}\text { Paracomesoma hexa- } \\
\text { setosum Chitwood }\end{array}$ & $33 \pm 28$ & 2 \\
\hline $\begin{array}{l}\text { Omnivore } \\
\text { (2B) }\end{array}$ & $\begin{array}{l}\text { Viscosia brachy- } \\
\text { laimoides Chitwood }\end{array}$ & $18 \pm 17$ & 6 & $\begin{array}{l}\text { Oncholaimoides } \\
\text { striatus Chitwood }\end{array}$ & $17 \pm 22$ & 5 \\
\hline
\end{tabular}

population parameter estimates. The choice of $3 \%$ encompassed the predominant species at each site.

Six species at the mud site and 5 species at the sand site each comprised more than $3 \%$ of the total nematode fauna respectively. Voucher specimens of these 11 specimens have been deposited in the nematology collections, National Museum of Natural History, Smithsonian Institution, Washington, D.C., USA. In Table 1 these species are listed along with their mean 3 yr abundance and rank. At the mud site the 6 species accounted for $53 \%$ of the total nematode abundance but at the sand site the 5 predominants accounted for $22 \%$ of the total nematodes. A higher species diversity in sand (123 species; $\mathrm{H}^{\prime} \log 10=3.12$ ) vs mud (98 species; $H^{\prime}=2.65$ ) meant that the predominant $(>3 \%$ ) species comprised a smaller percentage of the total fauna there.

The mean abundance of total individuals, females, gravid females and juveniles of Sabatieria kelleti at the mud site for each sampling are plotted in Fig. 2. $S$. kelleti is plotted only as an example. Similiar data and plots are available for all species, but the plots, while providing the mean $\pm \mathrm{SE}$ for each sampling, are complex and difficult to interpret. Thus, we have plotted the monthly means for the other 5 dominant species at the mud site, and the 5 dominants at the sand site (Fig. 3). These monthly means include the fortnightly abundance values from 1981 and 1982 . Life-history stages were not included because in every case the abundance patterns of the life-history stages (females, gravid females, etc.) were coincident in time with the total abundance patterns, as they are in $S$. kelleti (Fig. 2). A priori we expected time to be offset, e.g. first a peak (or lull) in ovigerous females, then juveniles, then totals but this was not the case when every data point for each category was overlain for each species. Sexes/life stages increased in parallel, with no apparent lag between gravid female and juvenile abundance peaks. The proportion of gravid females remained relatively constant for all species at both sites as illustrated for $S$. kelleti (Fig. 2); e.g. when total number of females increased, gravid females increased.

Four of the 6 most abundant species at the mud site varied seasonally, as did total nematodes, (1-way ANOVA: season/abundance, $p \leq 0.0001$ for the 4 species and the total; Table 2). Note that the congeneric Sabatieria's (Table 2) reached maximum abundance at different times of the year (see also Fig. 2 \& 3).

At the sand site neither Daptonema sp. nor Oncholaimoides striatus exhibited any significant seasonal change in abundance. For the remaining dominant species, only Paracomesoma hexasetosum was distinctly seasonal, being significantly more abundant in the spring and summer (Fig. 3; Table 2). While there was evidence of seasonality for Pomponema macrospiralis and Sabatieria armata, the only significant differences were between autumn and summer for $P$. macrospiralis and between winter and summer for S. armata (Table 2). Total nematode abundance was significantly lower in winter when compared to the other seasons (Table 2).

Between years only Sabatieria kelleti was significantly different in abundance in one year (1982) versus the other two $(1980,1981)$ at the mud site and Daptonema sp. was the only sand site species that was significantly different between years, i.e. in 1982 it was 


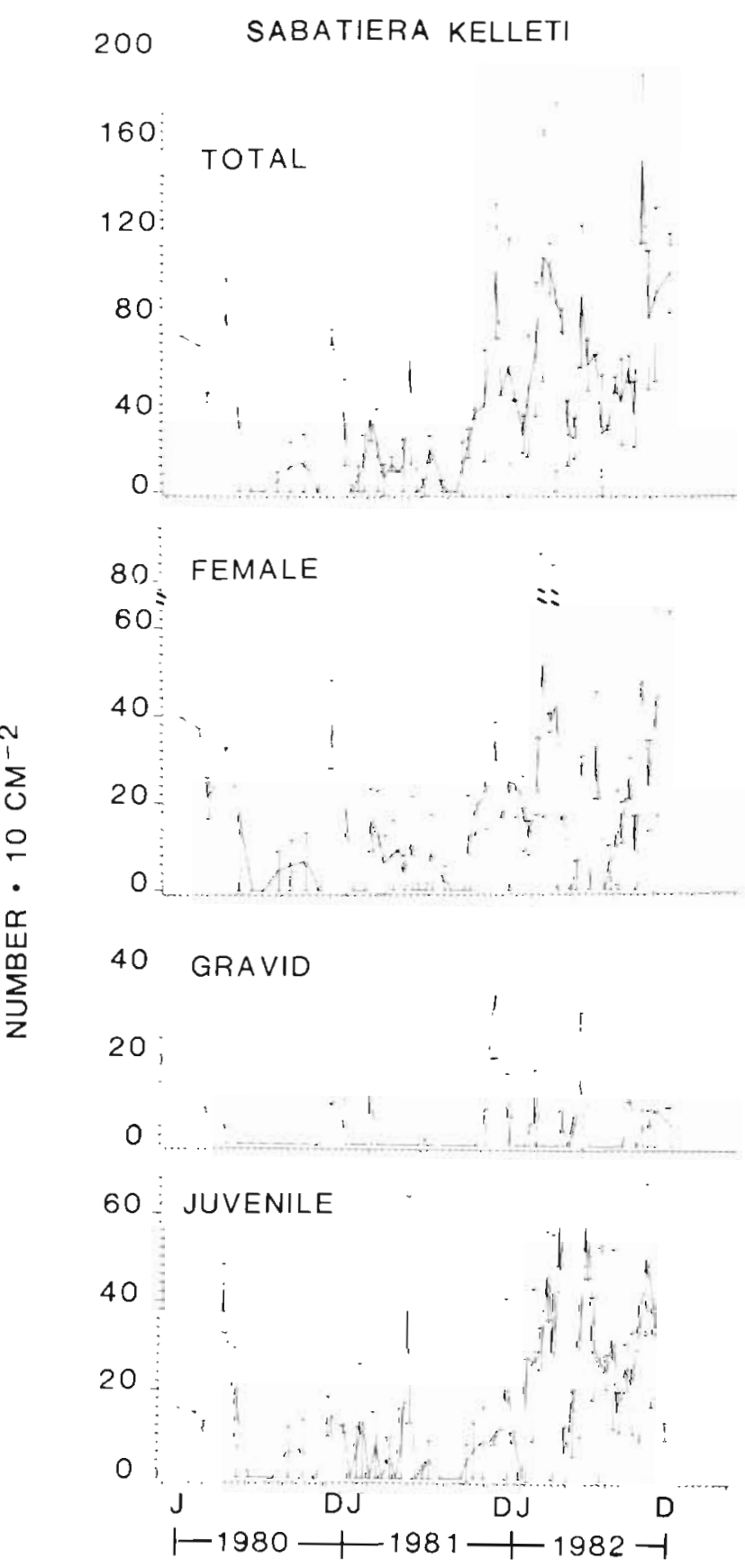

Fig. 2. Sabatieria kelleti. Mean abundance ( \pm SE) on each sampling date for totals, females, gravid females and juveniles

significantly lower in abundance than 1980 and 1981 (Table 3). At both sites total nematode abundance was greater in 1982 than in the previous 2 yr (Table 3).

In Table 4 we provicle the correlation coefficients for the dominant nematode species with measured physical parameters and microbial abundance. No species is correlated with bacterial abundance and only 3 of 11 with diatoms. Temperature correlates with 4 species; the maximum number of correlations for any parame- ter. The number of significant correlations when the 11 species ( 6 from mud and 5 from sand) were broken down into males, females, gravid females and juveniles, i.e. 11 species $\times 4$ life history categories $\times 5$ parameters $=220$ possible correlations, is similarly low. There were exactly 22 significant correlations of the 220 possible; none with bacteria, 1 with diatoms, 2 with salinity, 9 with depth of the redox layer and 10 with temperature. Since there were many tests in this study the probability that a type I error (rejecting the null hypothesis) occurs is very high and thus 22 of 220 correlations being significant is not beyond chance.

\section{DISCUSSION}

Abundance of the mud nematode fauna was much more variable seasonally than the sand fauna (Table 2). While only one species, Paracomesoma hexasetosum, was significantly distinct seasonally at the sand site (Fig. 3 ; Table 2) 3 of the 6 predominants (Daptonema erectum, Sabatieria americana, Ptycholaimellus hibernus) were distinctly seasonal at the mud site. Total nematode abundance at the mud site was highest in the winter i.e. January to March (Fig. 1; Table 2), and 5 of the 6 dominant species had their peak abundances in the winter or spring (Table 2). Only Sabatieria kelleti reached peak abundance in another season, i.e. autumn (Fig. 2; Table 2).

The peak winter/spring abundances at the mud site precede the annual arrival of large numbers of benthic feeding fish into the North Inlet ecosystem (Bozeman \& Dean 1980). Juvenile spot Leiostomus xanthurus are the chief juvenile fish recruited into the system and Smith \& Coull (1987) have experimentally demonstrated that juvenile spot selectively feed in muddy substrates, and in mud microcosms they reduced nematode abundance by $40 \%$ in $14 \mathrm{~h}$. There were no significant nematode reductions in the sandy portions of the Smith \& Coull microcosms. The coincidental decrease in total nematodes over 11 yr (Coull 1985) and the dominant species over 3 yr (Table 3 ) after the spot are known to have fed in the mud is certainly suggestive of predation.

Of all the nematodes $52 \%$ live in the upper $5 \mathrm{~mm}$ of muddy North Inlet sediments (P. Myers unpubl. student report), and spot feeding pits in the same North Inlet habitat average 2 to $2.3 \mathrm{~mm}$ deep (L. Billheimer unpubl. student report). While we do not know the daily ration of a juvenile spot, it has been reported that predation on nematodes by a crab (Reise 1979) and a goby (Fitzhugh \& Fleeger 1985) only reduced nematode abundances in the upper $5 \mathrm{~mm}$ of sediment; below $5 \mathrm{~mm}$ there was no reduction. Thus, since spot feed in the upper $3 \mathrm{~mm}$ and most nematodes live in the 


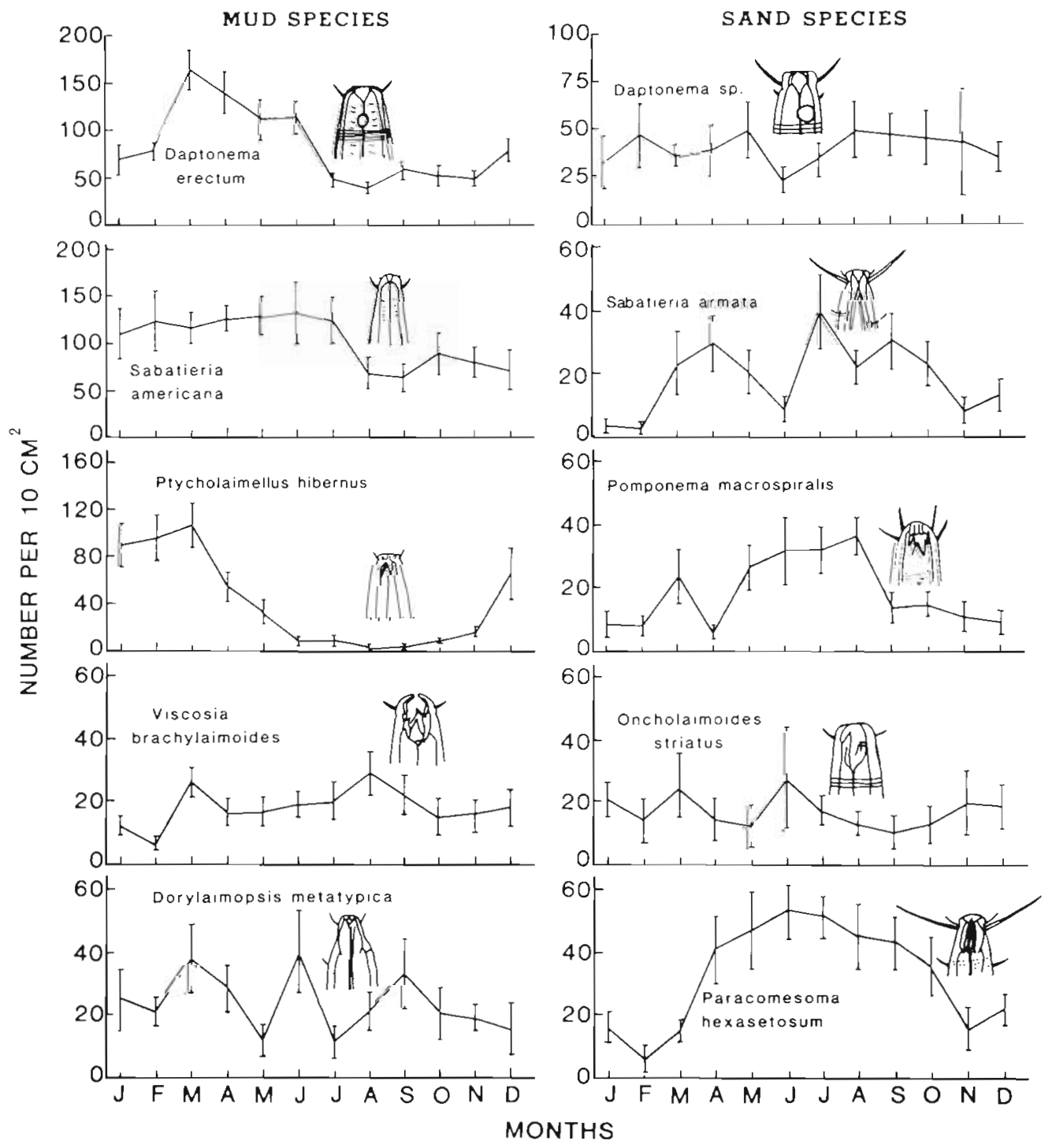

Fig. 3. Monthly mean abundances ( \pm SE) of 5 of the 6 dominant species at the mud site (see Fig. 2 for the sixth dominant species, Sabatieria kelleti) and the 5 dominant species at the sand site

upper $5 \mathrm{~mm}$ where they are most susceptible to predation, we suspect that juvenile spot predation is regulating the recorded annual late-spring field decreases in nematode abundances at the mud site (Fig. 1 \& 3; Table 2).

At the sand site 4 of the 5 dominant species reached maximum abundance in the summer or spring, as did total nematodes (Fig. 1; Table 2). Over the 3 yr, winter was the only season where total nematodes were significantly lower in abundance (Table 2); over 13 yr there were no seasonal abundance differences for total nematodes (Coull 1985, unpubl.). Thus, total nematode seasonality is either limited ( 3 yr of data) or absent (13 yr of data) at the sand site and since only one species, Paracomesoma hexasetosum, is distinct in its seasonality, seasonality at the sand site is somehow depressed. This relative lack of seasonality may be related to the high degree of hydrodynamic activity at the sand site.

A priori we expected the mud to provide a less disturbed/more stable' habitat than the hydrodynamically active sand with its megaripples and significant amount of crossbedding (Grant 1981, Montagna et al. 1983). If habitat 'stability' (sensu Sanders 1968) is an important factor regulating abundance patterns, our mud populations should have shown less fluctuation temporally than the sand; but this was not the case. As an hypothesis, then, we propose that the frequent hydrodynamic disturbances at the sand site maintain the fauna in a relatively constant state over time, while at the mud site, biological factors (predation?), and not hydrodynamic ones, regulate and cause the temporal 
Table 2. Seasonal rank abundance of the 6 most abundant species at the mud site and the 5 most abundant at the sand site Seasons with common underlines are not significantly different in abundance (Tukey's multiple comparison procedure; experimentwise error rate $p<0.05$ ). Seasons are: W, winter; Sp, Spring; Su, summer; A, autumn

\begin{tabular}{|c|c|c|c|c|}
\hline Mud site & \multicolumn{3}{|c|}{$\begin{array}{l}\text { Seasons } \\
\text { (mean abundance } 10 \mathrm{~cm}^{-2} \text { for that season) }\end{array}$} & \\
\hline $\begin{array}{l}\text { Mud site } \\
\text { Daptonema erectum }\end{array}$ & $\begin{array}{r}\mathrm{Sp} \\
(122) \\
\end{array}$ & $\begin{array}{r}W \\
(107)\end{array}$ & $\begin{array}{r}A \\
(57)\end{array}$ & $\begin{array}{r}\text { Su } \\
(46)\end{array}$ \\
\hline Sabatieria americana & $\begin{array}{r}\text { Sp } \\
(129) \\
\end{array}$ & $\begin{array}{r}\text { W } \\
(117)\end{array}$ & $\begin{array}{r}\mathrm{Su} \\
(85)\end{array}$ & $\begin{array}{r}A \\
(81)\end{array}$ \\
\hline Sabatieria kelleti & $\begin{array}{r}\text { A } \\
(60)\end{array}$ & $\begin{array}{r}\text { Sp } \\
(41)\end{array}$ & $\begin{array}{r}W \\
(41)\end{array}$ & $\begin{array}{r}\mathrm{Su} \\
(21)\end{array}$ \\
\hline Pytcholaimellus hibernus & $\begin{array}{r}W \\
(97) \\
\end{array}$ & $\begin{array}{r}\text { Sp } \\
(32)\end{array}$ & $\begin{array}{r}A \\
(25)\end{array}$ & $\begin{array}{l}\mathrm{Su} \\
(4) \\
\end{array}$ \\
\hline Dorylaimopsis metatypica & $\begin{array}{r}W \\
(28)\end{array}$ & $\begin{array}{r}5 p \\
(27) \\
\end{array}$ & $\begin{array}{r}\mathrm{Su} \\
(22)\end{array}$ & $\begin{array}{r}A \\
(19)\end{array}$ \\
\hline Viscosia brachylaimoides & $\begin{array}{r}\text { Su } \\
(24)\end{array}$ & $\begin{array}{r}\mathrm{Sp} \\
(18)\end{array}$ & $\begin{array}{r}A \\
(16)\end{array}$ & $\begin{array}{r}W \\
(15) \\
\end{array}$ \\
\hline Total nematodes & $\begin{array}{r}W \\
(804)\end{array}$ & $\begin{array}{r}\mathrm{Sp} \\
(695) \\
\end{array}$ & $\begin{array}{r}\text { A } \\
(577) \\
\end{array}$ & $\begin{array}{r}\mathrm{Su} \\
(452) \\
\end{array}$ \\
\hline $\begin{array}{l}\text { Sand site } \\
\text { Daptonema sp. }\end{array}$ & $\begin{array}{r}\mathrm{Su} \\
(41)\end{array}$ & $\begin{array}{r}A \\
(39) \\
\end{array}$ & $\begin{array}{r}W \\
(37)\end{array}$ & $\begin{array}{r}\mathrm{Sp} \\
(36) \\
\end{array}$ \\
\hline Sabatieria armata & $\begin{array}{r}\text { Su } \\
(29) \\
\end{array}$ & $\begin{array}{r}\mathrm{Sp} \\
(19) \\
\end{array}$ & $\begin{array}{r}\text { A } \\
(15) \\
\end{array}$ & $\begin{array}{l}W \\
(9)\end{array}$ \\
\hline Pomponema macrospiralis & $\begin{array}{r}\text { Su } \\
(27) \\
\end{array}$ & $\begin{array}{r}\mathrm{Sp} \\
(21) \\
\end{array}$ & $\begin{array}{r}W \\
(13) \\
\end{array}$ & $\begin{array}{r}A \\
\text { (11) }\end{array}$ \\
\hline Oncholaimoides striatus & $\begin{array}{r}W \\
(20) \\
\end{array}$ & $\begin{array}{r}\mathrm{Sp} \\
(18)\end{array}$ & $\begin{array}{r}A \\
(16)\end{array}$ & $\begin{array}{r}\text { Su } \\
(11) \\
\end{array}$ \\
\hline Paracomesoma hexasetosum & $\begin{array}{r}\mathrm{Sp} \\
(47)\end{array}$ & $\begin{array}{r}\text { Su } \\
(46) \\
\end{array}$ & $\begin{array}{r}\text { A } \\
(26)\end{array}$ & $\begin{array}{r}W \\
(13)\end{array}$ \\
\hline Total nematodes & $\begin{array}{r}\text { Su } \\
(651)\end{array}$ & $\begin{array}{r}\text { Sp } \\
(615)\end{array}$ & $\begin{array}{r}\text { A } \\
(534)\end{array}$ & $\begin{array}{r}W \\
(435)\end{array}$ \\
\hline
\end{tabular}

variability. If our hypothesis is correct, we should expect to see biologically controlled assemblages more variable in time than those under constant physical perturbation.

Comparing years over the $3 \mathrm{yr}$ period, the seasonal differences between sites disappear. There are few differences between years in the abundance of a particular species with only Sabatieria kelleti (mud site) and Daptonema sp. (sand site) being significantly different in one year versus the other two (Table 3). Thus, our hypothesis on the controls of temporal variability appears to be operating within a year; differences between years are an enigma.

Our correlation analyses provided little insight into species dynamics, especially with respect to trophic interactions. For example, Daptonema erectum ingests diatoms in large quantity; frequently its gut is packed with them (pers. obs.); yet, it was not correlated with diatom abundance (Table 4). Perhaps: (1) D. erectum is a generalist feeder and can substitute bacteria, detritus or microphytoflagellates if diatom abundance is low and thus it is not food limited; (2) D. erectum is rather restricted in diet and was not correlated with total diatom abundance because it ate only one to a few diatom species which were not reflected in the pattern of total diatom abundance; or (3) diatoms are not in short supply. The first hypothesis seems most reasonable because we have observed numerous species and sizes of diatoms in the gut along with 'detritus', chloroplasts or microphytobenthos. Montagna (1984) has shown that diatoms were selected 14 times more than bacteria by in situ nematodes in North Inlet. However, 
Table 3. Yearly rank abundance of the 6 most abundant species at the mud site and the 5 most abundant at the sand site. Years with common underlines are not significantly different in abundance (Tukey's multiple comparison procedure; experimentwise error rate $\mathrm{p}<0.05$ )

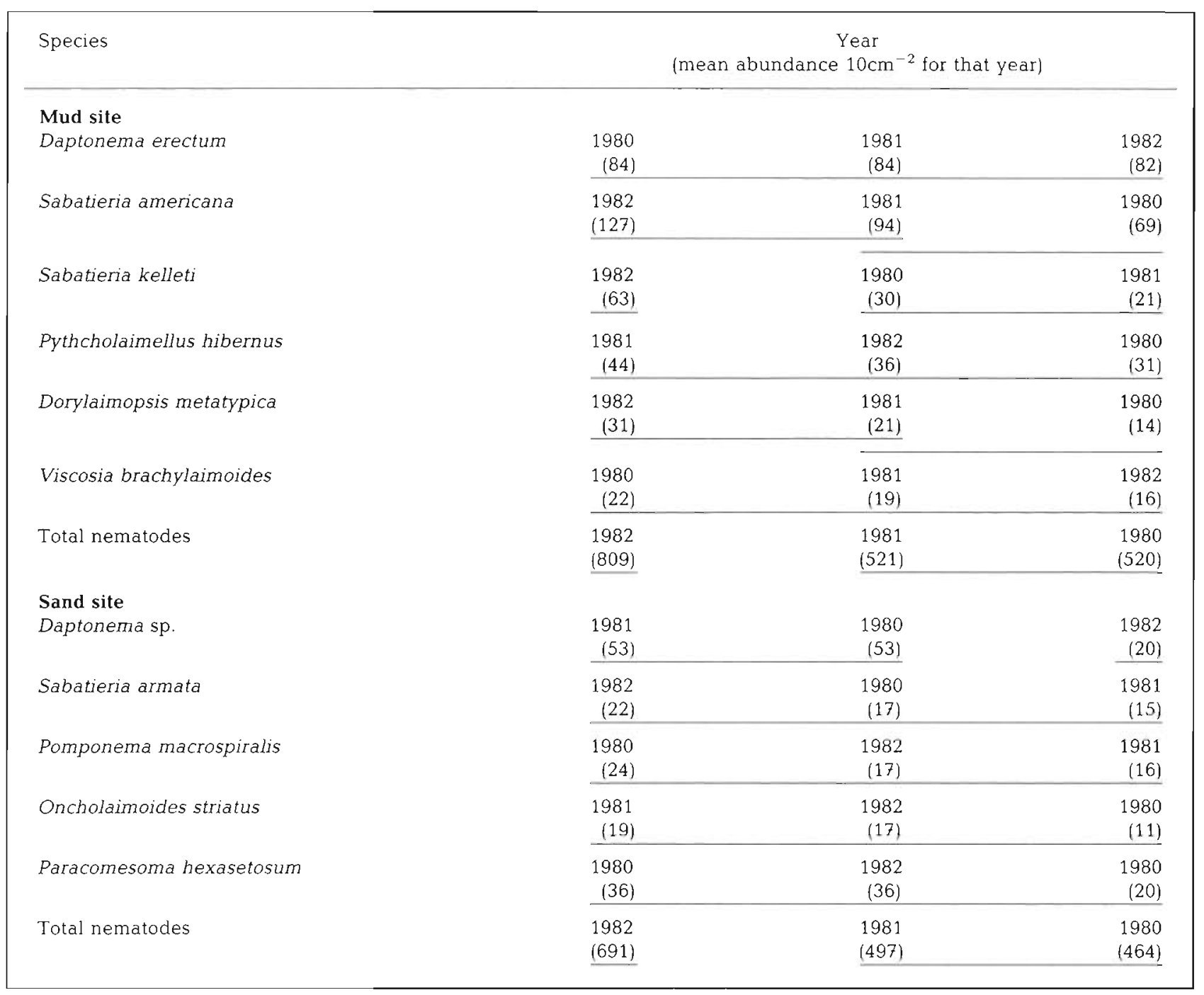

meiofauna in general (nematodes comprise $>70 \%$ of the total meiofauna) do not have a great impact on the diatom populations, i.e. diatoms have a $3.5 \mathrm{~d}$ turnover rate which outpaces the meiofauna grazing rate. If diatoms were limiting, meiofaunal (nematode) abundance would be expected to follow fluctuations in diatom abundance; but it did not (Table 4 ; Montagna et al. 1983) and with few correlations between nematodes and diatoms (Table 4), we must conclude that diatom abundance does not limit nematode abundance. Admiraal et al. (1983) came to the same conclusion in the Ems-Dollard estuary in The Netherlands.

The completely negative results of the correlations with bacteria may be more informative. Since strictly bacterivorous nematodes were not among the predominant nematodes at either site (Table 1), it is not surprising that there were no correlations between bacteria and a nematode's species abundance. While laboratory in vitro culture has clearly demonstrated that certain nematode species can be raised on bacteria (e.g. Tietjen 1967, Tietjen \& Lee 1977, Romeyn \& Bouwman 1983) true bacterivores are typically low in abundance in most meiobenthic communities (Wieser 1959: 4.1 to $6.7 \%$; Tietjen 1969: $2 \%$; Boucher 1972: $2.4 \%$; Juario 1975: $6.8 \%$ ). In our sites they comprised $<2 \%$ of the sand fauna and $3.6 \%$ of the mud fauna. Thus, extrapolation of laboratory feeding rates to mixed species populations in the field to estimate trophic input to the nematodes must consider the relative proportions of the different nematode trophic groups. Ignoring such feeding preferences can lead to erroneous conclusions.

The constant proportion of gravid females recorded 
Table 4. Pearson's correlation coefficients and significance levels for nematode species abundance with physical factors and microbes at both sites. Data for diatom and bacteria abundance are from Montagna et al. (1983) and for the period February 1981 through January 1982 only

\begin{tabular}{|c|c|c|c|c|c|}
\hline \multirow[t]{2}{*}{ Species } & \multicolumn{3}{|c|}{ Physical factors } & \multicolumn{2}{|c|}{ Microbes } \\
\hline & Temperature & Depth & Salinity & Diatoms & Bacteria \\
\hline \multicolumn{6}{|l|}{ Mud site } \\
\hline Sabatiena americana & -0.07 & -0.01 & $-0.28^{\circ}$ & $0.59^{\circ}$ & 0.31 \\
\hline Daptonema erectum & -0.23 & 0.23 & -0.21 & 0.33 & 0.27 \\
\hline Sabatieria kelleti & $-0.32^{*}$ & 0.10 & $-0.38 \cdots$ & -0.10 & 0.12 \\
\hline Pythcholaimellus hibernus & $-0.68 \cdots$ & $0.68 \cdots$ & -0.20 & $0.50^{\circ}$ & 0.30 \\
\hline Dorylaimopsis metatypica & -0.17 & 0.14 & -0.24 & -0.10 & 0.04 \\
\hline Viscosia brachylaimoides & 0.19 & -0.10 & 0.01 & 0.32 & 0.01 \\
\hline \multicolumn{6}{|l|}{ Sand site } \\
\hline Daptonema sp. & 0.04 & -0.04 & 0.18 & 0.20 & 0.28 \\
\hline Paracomesoma hexasetosum & $0.58^{\cdots}$ & -0.19 & -0.07 & 0.31 & 0.22 \\
\hline Sabatieria armata & $0.26^{\cdots}$ & -0.09 & -0.01 & 0.12 & 0.26 \\
\hline Pomponema macrospiralis & $0.36^{*}$ & -0.15 & 0.14 & $0.55^{\circ}$ & -0.07 \\
\hline Oncholaimoides striatus & -0.12 & 0.01 & 0.11 & 0.30 & -0.19 \\
\hline
\end{tabular}

suggests overlapping generations and/or a continuous or protracted reproductive periodicity (Heip et al. 1982). Our inability to distinguish a peak in ovigerous female abundance preceeding both a juvenile and total population abundance maximum for any species could be due, we feel, to 2 factors. First, all the eggs of a female or a population may not hatch simultaneously and the development rate of individual juveniles from the same clutch may not be synchronous after the eggs are hatched. Thus, hatching and development could be spread out over some time period (days to weeks?). Secondly, our shortest sampling interval of every $2 \mathrm{wk}$ in 1981-1982 may not have been adequate to distinguish either those species with protracted development or those with one or more cohorts within our sampling interval. Sampling interval could also affect the seasonal patterns recorded if the development period of the various species is within the $2 \mathrm{wk}$ period. Accurate determination of sequencing of life-history stages would require many replicated short-interval samples (daily to weekly). Since meiobenthic copepod cohorts are known to overlap in time (Fleeger 1979), and since nematodes are suspected of doing the same (Heip et al. 1982), it may be impossible to accurately assess lifehistory sequencing from even short-interval field data. Lab rearings would be necessary.

With 3 yr of nematode species data we feel confident that the seasonal patterns reported are relatively accurate. While abundance might change from year to year (e.g. there were 53 Daptonema sp. per $10 \mathrm{~cm}^{2}$ at the sand site in 1980 and 1981 and only 20 in 1982) the seasonal patterns were repeatable (Fig. 2). Longer-term patterns, of course, cannot be determined with only 3 yr of data and definition of such patterns obviously requires sampling on a longer scale. More important than the descriptive trends however, are the mechanisms controlling these trends. While correlation analysis (Table 4) provided little insight, it appears that the seasonal patterns at the 2 sites are controlled by different mechanisms. Predation is thought to be the mechanism controlling the seasonal abundance patterns at the mud site, whereas hydrodynamic activity is proposed as a mechanism maintaining the community at the sand site.

Acknowledgements. We thank Bettye W. Dudley for sorting, enumerating and removing the nematodes from all the samples; Melinda Crump and Laura Foster for mounting the nematodes; Bruce E. Hopper and W. Duane Hope for instructing RAE in nematode taxonomy and John W. Fleeger, John H. Tietjen, David S. Wethey, Sarah A. Woodin and 2 anonymous reviewers for constructive comments on earlier drafts of this manuscript. This research and writing was supported by the Biological Oceanography Section of the National Science Foundation through grants OCE 80-07968, OCE 83-08114 (B. C. Coull, principal investigator) and OCE 85-21345 (B. C. Coull \& R. J. Feller, P.I.'s) and the LTER Program of the Ecosystems section of NSF, Grant DEB 80-12165 (F. J. Vernberg, P. I.).

\section{LITERATURE CITED}

Admiraal, W., Bouwman, L. S., Hoekstra, L., Romeyn, K. (1983). Qualitative and quantitative interactions between microphytobenthos and herbivorous meiofauna on a brackish intertidal mudflat. Int. Revue ges. Hydrobiol. 68: 175-191

Boucher, G. (1972). Premiêres données ecologiques sur les nematodes libres marins d'une station de vase contiere de Banyuls. Vie Milieu 23: 69-100

Boucher, G. (1983). Evolution du meiobenthos des sables fins 
sublittoreaux de la Baie de Morlaix de 1972-1982. Oceanologica Acta, Spec. Vol., 33-37

Bozeman, E. L., Jr., Dean, J. M. (1980). The abundance of estuarine larval and juvenile fish in a South Carolina intertidal creek. Estuaries 3: 89-97

Coull, B. C. (1985). Long-term variability of estuarine meiobenthos: an 11 year study. Mar Ecol. Prog. Ser 24: 205-218

Eskin, R. A. (1985). Population dynamics and ecology of the meiobenthic nematodes of North Inlet, South Carolina. Ph. D. thesis, Univ. of South Carolina, Columbia

Fitzhugh, G. R., Fleeger, J. W. (1985). Goby (Pisces: Gobiidae) interactions with meiofauna and small macrofauna. Bull. mar. Sci. 36: 436-444

Fleeger, J. W. (1979). Population dynamics of three estuarine meiobenthic harpacticoids (Copepoda) in South Carolina. Mar. Biol. 52: 147-156

Gourbault, N. (1984). Fluctuations des peuplements de nematodes de chenal de la Baie de Morlaix 1. Resultats a moyen terme, après pollution par les hydrocarbures. Cah. Biol. mar. 25: 169-180

Gourbault, N. (1987). Long-term monitoring of marine nematode assemblages in the Morlaix Estuary (France) following the Amoco Cadiz oil spill. Estuar coast. Shelf Sci. 24: $657-670$

Grant, J. (1981). Factors affecting the occurrence of intertidal amphipods in reducing sediments. J. exp. mar. Biol. Ecol. 49: 203-216

Heip, C., Vinx, M., Smol, N., Vranken, G. (1982). The systematics and ecology of free-living marine nematodes. Helminthol. Abstracts, Ser. B., Plant Nematology 51: 1-31

Hicks, G. R. F., Coull, B. C. (1983). The ecology of marine meiobenthic harpacticoid copepods. Oceanogr. mar. Biol. A. Rev. 21: 67-175

de Jonge, V. N., Bouwman, L. (1977). A simple density separation technique for quantitative isolation of meiobenthos using the colloidal silica Ludox-TM. Mar. Biol. 42: 143-148

Juario, J. V. (1975). Nematode species composition and seasonal fluctuation of a sublittoral meiofauna community in the German Bight. Veröff. Inst. Meeresforsch. Bremerhaven $15: 283-337$

Kirk, R. E. (1982). Experimental design: procedures for the behavioral sciences, 2nd edn. Brooks/Cole Publishing Co., California
Montagna, P. A. (1984). In situ measurement of meiobenthic grazing rates on sediment bacteria and edaphic diatoms. Mar Ecol. Prog. Ser. 18: 119-130

Montagna, P. A., Coull, B. C., Herring, T L., Dudley, B. W. (1983). The relationship between abundances of meiofauna and their suspected microbial food (diatoms and bacteria). Estuar coast. Shelf Sci. 17: 381-394

Reise, K. (1979). Moderate predation on meiofauna by the macrobenthos of the Wadden Sea. Helgoländer wiss. Meeresunters. 32: 453-465

Romeyn, K., Bouwman, L. A. (1983). Food selection and consumption by estuarine nematodes. Hydrobiological Bull. 17: 103-109

Sanders, H. L. (1968). Marine benthic diversity: a comparative study. Am. Nat. 102: 242-283

SAS Institute Inc. (1982). SAS user's guide: statistics. SAS Institute Inc. Cary, North Carolina

Seinhorst, J. W. (1959). A rapid method for the transfer of nematodes from fixative to anhydrous glycerine. Nematologica 4: 67-69

Smith, L. D., Coull, B. C. (1987). Juvenile spot (Pisces) and grass shrimp predation on meiobenthos in muddy and sandy substrata. J. exp. mar. Biol. Ecol. 105: 123-136

Tietjen, J.H. (1967). Observations on the ecology of the marine nematode Monhystera filicaudata Allgen, 1929. Trans. Am. microsc. Soc. 86: 304-306

Tietjen, J. H. (1969). The ecology of shallow water meiofauna in two New England estuaries. Oecologia (Berl.) 2: $251-291$

Tietjen, J. H., Lee, J. J. (1977). Feeding behavior of marine nematodes. In: Coull, B. C. (ed.) Ecology of marine benthos. Univ. of South Carolina Press, Columbia, p. 22-36

Wieser, W. (1953). Die Beziehung zwischen Mundhöhlengestalt, Ennährungsweise und Verkommen bei freilebenden marinen Nematoden. Eine ökologisch-morphologische Studie. Ark. Zool. Ser. III 4: 439-484

Wieser, W. (1959). Free-living marine nematodes. IV. General part. Reports of the Lund University Chile Expedition 1940-49. Lunds Univ. Arsskr., N.F. Avd 2, 55 (5): 1-110

Wieser, W. (1960). Benthic studies in Buzzards Bay II. The meiofauna. Limnol. Oceanogr. 5: 121-137

This article was presented by Professor K. R. Tenore; it was accepted for printing on September 3, 1987 